№ 1 (4), 2021

УДК 621.311.25

I. 3. Щур,

Національний університет “Львівська політехніка”, кафедра електромехатроніки і комп’ютеризованих електромеханічних систем, ihor.z.shchur@1pnu.ua

Т. В. Галайко,

Національний університет “Львівська політехніка”, кафедра електромехатроніки і комп’ютеризованих електромеханічних систем, tetiana.v.halaiko@lpnu.ua

Т. Я. Дзьоба

Національний університет “Львівська політехніка", кафедра електромехатроніки і комп’ютеризованих електромеханічних систем, tdzoba@gmail.com

\title{
ЕКОНОМІЧНА ЕФЕКТИВНІСТЬ СОНЯЧНОЇ ЕЛЕКТРОСТАНЦІЇ В ІНДИВІДУАЛЬНОМУ ДОМОГОСПОДАРСТВІ ЗА РІЗНИХ СЦЕНАРІЇВ ДИНАМІКИ “ЗЕЛЕНОГО” ТАРИФУ
}

http://doi.org/10.23939/sepes2021.01.087

( Щур I. 3., Галайко Т. В., Дзьоба Т. Я., 2021

\begin{abstract}
“Зелений” тариф - спеціальна ціна, за якою купують електричну енергію, вироблену відновлюваними джерелами енергії - гідроелектростанціями, сонячними, вітровими установками. Підприємства і домогосподарства, які виробляють електроенергію за "зеленим" тарифом, продають її на ринок значно дорожче, ніж традиційні виробники теплової або атомної енергетики. У роботі проаналізовано законодавчі та нормативні акти щодо “зеленого" тарифу в Україні та проблеми їх виконання. Зокрема, розглянуто застосування сонячних електричних станцій (СЕС) в індивідуальних домогосподарствах. На основі електронної інформаційної бази погодинних регіональних метеорологічних даних у м. Львові, сформованої в середовищі Microsoft Excel, проведено розрахунок середньомісячного погодинного притоку питомої потужності сумарної сонячної радіації, що падає на стаціонарно розміщені й оптимально оріснтовані фотоелектричні панелі (ФЕП), та визначено потужність електричної енергії на їх виході. За результатами аналізу інформації з різних джерел визначено динаміку вартостей основних комплектуючих для індивідуальних СЕС, а також наведено аналіз динаміки та прогноз тарифу на електричну енергію для населення в Україні. На основі аналізу ситуації на енергоринку України розглянуто два можливі сценарії динаміки “зеленого" тарифу на електроенергію, генеровану в індивідуальних господарствах з сонячної енергії, - оптимістичний $i$ песимістичний. Для кожного 3 цих сценаріїв на основі розробленої методики для СЕС потужністю 30 кВТ, встановлених у 2015 р. та 2021 р. в досліджуваному типовому варіанті домогосподарства, визначено їх економічну ефективність і термін окупності. Проведені дослідження показали, що на термін окупності СЕС найбільше впливас рік її встановлення: СЕС, які встановлюються пізніше, мають значно коротший термін окупності, що пов'язано зі стрімким зниженням вартості ФЕП. Розглянуті варіанти сценаріїв динаміки “зеленого” тарифу показали, що за оптимістичного сценарію можна отримати на 30-40 \% більший прибуток від експлуатації СЕС порівняно з песимістичним сценарієм, незалежно від року встановлення СЕС.

Ключові слова: “зелений” тариф; фотоелектрична установка, сонячна електрична станція; відновлювальні джерела енергїі; погодинні метеорологічні дані.
\end{abstract}




\section{3. Щур, Т. В. Галайко, Т. Я. Дзьоба}

\section{Постановка задачі}

Відновлювані джерела енергії (ВДЕ) здатні забезпечити достатнє виробництво електричної та теплової енергії, яку потребують промисловість, транспорт і сільське господарство у світовому масштабі. Протягом останніх десятиліть найбільшим у галузі відновлюваної енергетики $є$ попит на станції та установки, що генерують електроенергію (ЕE) від енергії сонячного випромінювання. Крім великої енергетики, у якій застосовують потужні сонячні електричні станції (CЕС), останнім часом щораз більшої популярності набувають малопотужні фотоелектричні установки (ФЕУ), які можуть забезпечувати потреби окремих споживачів ЕE, сприяючи тим самим децентралізації ii генерування.

3 метою стимулювання розвитку сонячної електроенергетики багато країн світу створюють комфортні умови для використання цього екологічно чистого джерела енергії, видаючи кредити та оформляючи документи на використання “зеленого” тарифу, за рахунок якого можна набагато швидше повернути вкладені у систему кошти.

В Україні “зелений” тариф застосовується і для приватних осіб (з початку 2014 р. набрав чинності Закон України “Про електроенергетику"), тобто власники індивідуальних СЕС потужністю до 30 кВт скидають надлишок генерованої ЕЕ в регіональну електромережу, а держава купує його за високими цінами [1]. Отже, власник домогосподарства економить на покупці обладнання, передусім, сонячних фотоелектричних панелей (ФЕП) та інвертора для власної станції, що робить цю систему економічно вигідною. Період окупності обладнання істотно скорочується. Особливість “зеленого” тарифу в Україні полягає в тому, що ціна, за якою держава купує у виробника ЕE, залежить від часу, коли об' єкт був введений в експлуатацію, а вартість електроенергії, яка діяла на момент початку експлуатації, зберігається на весь час іï подальшої роботи (для України це 2030 рік).

\section{Аналіз останніх досліджень і публікацій}

Технічні засоби відновлюваної енергетики, як правило, мають високу вартість. У сонячній фотоенергетиці основними дорогими технічними засобами є ФЕП, інвертори напруги та пристрої механічної і електричної інсталяції СЕС. Враховуючи великі початкові капітальні затрати, важливим $\epsilon$ оцінка таких показників доцільності спорудження СЕС, як термін окупності затрат та економічна ефективність експлуатації. Ці показники тісно пов'язані з оцінкою генерування ЕЕ протягом року і всього терміну служби, а також з тарифами на ЕЕ. Серед наукових досліджень можна знайти багато таких, що спрямовані на техніко-економічне обгрунтування доцільності спорудження за різних умов систем генерування ЕЕ з відновлюваних джерел енергії , в тому числі й СЕС різної потужності [2-7].

У роботах [2-4] детально розглядаються техніко-економічні аспекти застосування різних гібридних систем енергозабезпечення: реальних проектів реалізації автономних вітросонячних установок для електростачання відділеного селища на Тайвані [2] та в Алжирі [3]; автономного електрозабезпечення на основі фотоелектричної та вітрової установок, дизельного генератора, акумуляторних батарей, а також установки опріснення води за методом зворотного осмосу [4]. У цих дослідженнях, поряд з обгрунтуванням оптимальних співвідношень генеруючих потужностей окремих засобів та акумулюючих ємностей нагромаджувачів енергії, особлива увага звернена на оцінку таких економічних показників проектів як кошторисна вартість, ризики інвестицій, економічна ефективність і термін окупності затрат. Робота [5] присвячена конкретній розробці приватної мережевої СЕС потужністю 10 кВт в Індії, для якої автори порівнюють терміни окупності за різних рівнів державних субсидій. При цьому, поряд із детальною оцінкою погодних умов, вартістю обладнання і робіт щодо спорудження СЕС, економічними показниками, такими як рівень інфляції та ставка дисконтування, враховується також деградація сонячних фотоелектричних панелей в процесі експлуатації і зниження їх продуктивності.

Подібні дослідження проводяться і в Україні. Так, в роботі [6] розроблено методику розрахунку та вибору комбінованої системи електропостачання, що враховує існуючу систему оплати за ЕЕ в комунально-побутовому секторі, режими електроспоживання від декількох джерел енергії, вартість спорудження та строки окупності проектних рішень, зокрема й для сонячних систем електропостачання. Робота [7] особлива тим, що в ній досліджується прогнозна 
ефективність застосування гібридних сонячних колекторів, які здатні генерувати одночасно EЕ i теплову енергію для багатоквартирних будинків. Новизна роботи полягає в тому, що прогнозування ефективності проводилося з урахуванням динаміки за останні роки та екстраполяції трендів цін до 2045 року на ринку відновлюваної енергетики. При цьому враховано динаміку основного та “зеленого” тарифів на сонячну електричну і теплову енергію.

Підприємства і домогосподарства, які виробляють ЕЕ за “зеленим” тарифом, продають іï на ринок значно дорожче, ніж традиційні виробники теплової або атомної енергетики. Всю вироблену в країні ЕЕ, зокрема дорогу “зелену”, скуповує так званий Оптовий ринок (Державне підприємство (ДП) “Гарантований покупець”) за різними тарифами - залежно від типу виробника. Та сама установа потім продає скуплену ЕЕ енергопостачальним компаніям, які доставляють ії населенню. Тобто рахунок, який сплачують кінцеві споживачі, містить також витрати на дорогу “зелену” ЕЕ [8].

У Законі України “Про електроенергетику” (зі змінами і доповненнями від 11.06.2017р.) [9], у разі виробництва ЕЕ 3 енергії сонячного випромінювання для приватних домогосподарств, договір про купівлю-продаж ЕЕ яких укладено з 1 липня 2015 року, “зелений” тариф встановлено на рівні 20 євроцентів/кВт·год. Для наступних років цей тариф дещо знижується, а 31 січня 2025 року становитиме 14,5 євроцента/кВт·год, тобто залишається доволі високим.

Високі тарифи спричинили бум у “зеленій” енергетиці [10]. 2017 р. встановлена потужність ВДЕ в Україні зросла на 30 \%, 2018 р. - на 66 \%, 2019 р. - на $200 \%$, тобто втричі. Близько 80 \% “зеленоі” енергетики в Україні припадає на СЕС. Усе це відбувається на фоні стрімкого зниження вартості ФЕП, які з 2011 р. подешевшали майже в дев'ять разів - 3 2,33 \$/Вт до 0,27 \$/Вт. Тобто "зелена" енергетика для виробників стає щораз вигіднішою: вкладати треба менше, а тариф залишається стабільно високим. У 2020 р. через масовий запуск нових альтернативних енергопроєктів за "зелену" енергію потрібно було заплатити понад 50 млрд грн. Це майже в чотири рази більше, ніж ще два роки тому. У ДП “Гарантований Покупець” не знайшлося стільки грошей, і в останні місяці рівень розрахунків упав до 4-5\%. У результаті накопичуються гігантські борги (близько 17 млрд грн) без механізму їх погашення. Тому зміни були необхідні. Виробники погодилися на зменшення тарифів, а держава зобов' язалася погасити заборгованість із “зеленого” тарифу до кінця 2021 р. [11]. Термін дії “зеленого” тарифу депутати залишили незмінним - до кінця 2029 р. Але його розмір зменшують упровадженням понижувальних коефіцієнтів, які залежать від потужності CEC і часу введення їх в експлуатацію. Вони стосуються переважно потужних СЕС мегаватного класу, роботу яких, крім цього, треба балансувати за рахунок інших генеруючих потужностей чи застосування енергосховищ, які є непростими та дорогими.

Зважаючи на описані проблеми “зеленої" енергетики в Україні, ситуація дуже напружена, задавнена, і не видно позитивного виходу з неї. Тому можна очікувати різних законодавчих заходів, які можуть кардинально змінити ситуацію у відновлювальній електроенергетиці. Це дослідження спрямоване саме на оцінку ризиків, які постають перед тими індивідуальними побутовими споживачами, які вже встановили у своїх домогосподарствах CEC, а також перед тими, які збираються це зробити.

\section{Ціль статті}

Мета статті - розроблення на основі регіональних погодинних метеорологічних даних математичної моделі помісячного генерування електричної енергії СЕС та оцінювання економічної ефективності спорудження і функціонування цієї СЕС в індивідуальному домогосподарстві за різних прогнозованих сценаріїв динаміки “зеленого” тарифу в Україні.

\section{Виклад основного матеріалу \\ Аналіз притоку сонячної радіації та питомої кількості електричної енергії, генерованої СЕС у Львівському регіоні}

Величина притоку енергії сумарної сонячної радіації (СР) на ФЕП залежить від місця розміщення та орієнтації панелі, кута її нахилу до горизонту, пори року, часу доби, погоди та низки інших факторів [12]. До складу сумарної сонячної радіації входить пряма СР, що надходить на 
світлопоглинальну поверхню від сонця, та розсіяна небосхилом СР [13]. У похмурі дні розсіяна СР $\epsilon$ єдиним джерелом енергії в приземних шарах атмосфери.

Питому потужність притоку сумарної СР $S\left[\mathrm{BT} / \mathrm{M}^{2}\right]$ можна розрахувати за виразом:

$$
S=S_{\text {п }}+S_{\mathrm{p}}
$$

де $S_{\text {п та }} S_{\mathrm{p}}$ - питомі потужності притоку відповідно прямої та розсіяної СР.

Схему притоків $S_{\text {п та } S_{\mathrm{p}} \text { показано на рис. } 1 .}$

Питома потужність притоку прямої СР на орієнтовану довільно площину дорівнює

$$
S_{\text {п }}=S_{\mathrm{M}} \cos \theta,
$$

де $S_{\mathrm{M}}$ - питома потужність притоку прямої СР біля земної поверхні на перпендикулярну до сонячних променів площину; $\theta$ - кут між перпендикуляром до площини та напрямом на Сонце.

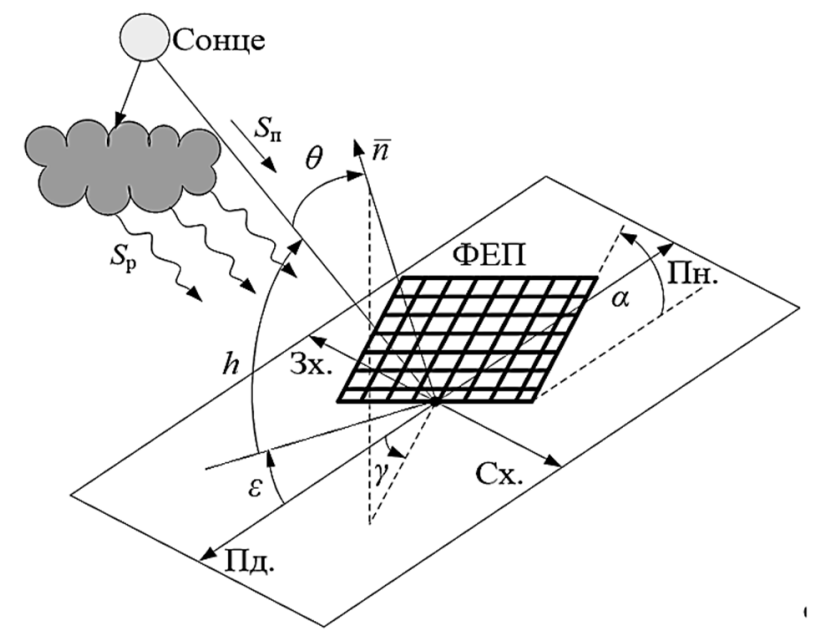

Рис. 1. Схема притоків потужностей прямої $S_{n}$ і розсіяної $S_{p} C P$ та параметри орієнтаџії ФЕП відносно горизонтальної площчини

Питома потужність притоку прямої СР залежить від товщини атмосфери, через яку проходять промені. Її можна розрахувати за емпіричним виразом [14]

$$
S_{\mathrm{M}}=1085,46-194,1(\sin h)^{-1}+11,36(\sin h)^{-2},
$$

де $(\sin h)^{-1}$ - відносна повітряна маса (набуває найменшого значення, коли Сонце розташоване в зеніті), в. о; $h$ - кут висоти сонця.

На рис. 1 орієнтація ФЕП у просторі визначається такими кутами: $\alpha$ - кут нахилу ФЕП (кут між ФЕП і горизонтальною площиною); $\gamma$ - азимутальний кут сприймаючої площини, який дорівнює куту між меридіальним напрямком Пн.-Пд. і проєкцією нормалі до сприймаючої поверхні на площину горизонту (кут $\gamma<0$ за відхилення на схід і $\gamma>0$ - на захід).

Косинус кута $\theta$ розраховують за таким співвідношенням [15]:

$$
\cos \theta=(A-B) \sin \delta+\left[C \sin \beta_{г}+(D+E) \cos \beta_{г}\right] \cos \delta,
$$

де $A=\sin \varphi \cos \alpha ; B=\cos \varphi \sin \alpha \cos \gamma ; C=\sin \alpha \sin \gamma ; D=\cos \varphi \cos \alpha ; E=\sin \varphi \sin \alpha \cos \gamma$.

Схилення сонця $\delta$ визначають за співвідношенням

$$
\delta=23,45 \sin \left[(284+N) \frac{2 \pi}{365}\right],
$$

де $N$ - порядковий номер дня року (починаючи з 1, що відповідає 1 січня).

Кут висоти сонця $h$ можна обчислити за виразом

$$
h=\arcsin \left(\sin \varphi \sin \delta+\cos \varphi \cos \delta \cos \beta_{\mathrm{r}}\right) .
$$


Економічна ефективність сонячної електростаниії в індивідуальному домогосподарстві...

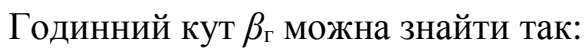

$$
\beta_{\mathrm{r}}=(t-12) \frac{\pi}{12}
$$

де $t$ - час доби, год.

Потужність притоку розсіяної СР можна розрахувати за виразом [14]

$$
S_{\mathrm{p}}=137,1-28,82(\sin h)^{-1}+2,27(\sin h)^{-2} \text {. }
$$

У цій роботі використана сформована в [16] електронна інформаційна база погодинних регіональних (м. Львів) метеорологічних даних (ЕБМД) в середовищі Microsoft Excel. До бази входять погодинні за 2013 р. дані про швидкість вітру, напрямок вітру, відносні тривалості (у в. о.) ясності та хмарності в інтервалах істинного часу, а також температуру навколишнього середовища.

Прийнято оптимальне для місцевості м. Львова встановлення ФЕП: орієнтація на південь географічна $\varphi=49^{\circ}, \alpha_{\mathrm{opt}}=35^{\circ}$ [17]. Значення середніх питомих потужностей притоків складових СР прямої $S_{\text {п. } i}$ та розсіяної $S_{\mathrm{p} . i}$ на встановлено нерухомо площину для $i$-ї години обчислено за виразами (1)-(8). Маючи ЕБМД з погодинною інформацією про відносні тривалості ясності $T_{\text {я. }}$ * та хмарності $T_{\mathrm{x} . i^{*}}$, за розрахованими на $i$-ту годину значеннями $S_{\text {п. } i}$ та $S_{\mathrm{p} . i}$ обчислювали погодинні кількості надходження на $1 \mathrm{~m}^{2}$ оптимально розміщеної ФЕП енергії сумарної (прямої та розсіяної) $\mathrm{CP} W_{\mathrm{C} . i}$ $($ Вт·год/м²):

$$
W_{\mathrm{C} . i}=W_{\mathrm{n} . i}+W_{\mathrm{p} . i}
$$

де $W_{\text {п. } i}=S_{\text {п.i }} T_{\text {я. } i^{*}}-$ енергія прямої СР, що падає, протягом $i$-ї години; $W_{\mathrm{p} . i}=S_{\mathrm{p} . i} T_{\mathrm{x} . i^{*}}-$ енергія розсіяної СР, яка падає упродовж $i$-ї години.

Розподіл середньомісячного добового значення енергії сумарної СР, що надходить на одиницю площі ФЕП, розраховано за таким співвідношенням:

$$
\bar{W}_{\mathrm{C} . k}=\frac{\sum_{i=1}^{n_{k}} W_{\mathrm{C} . i . k}}{m_{k}},
$$

де $W_{\text {C.i.k }}$ - значення енергії сумарної СР, що надходить на $1 \mathrm{~m}^{2}$ ФЕП, за $i$-ту годину $k$-го місяця; $m_{k}-$ кількість днів у $k$-му місяці.

На рис. 2 подано, для прикладу, середньомісячні добові погодинні розподіли енергії сумарної СР, що надходить на $1 \mathrm{~m}^{2}$ ФЕП, розраховані за (10).

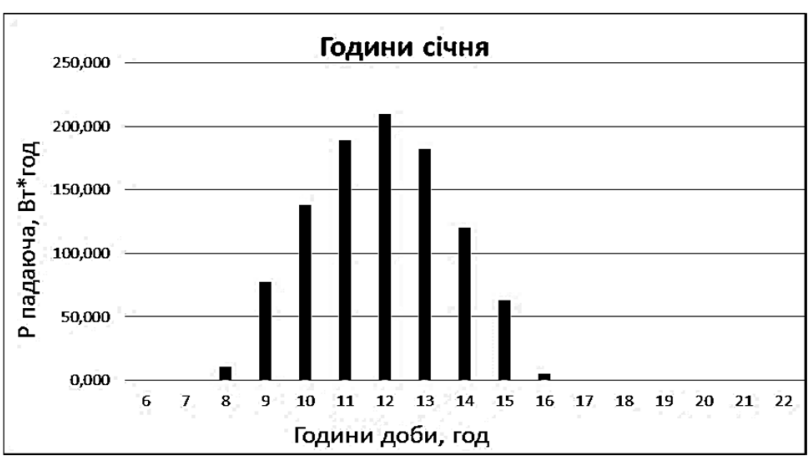

$a$

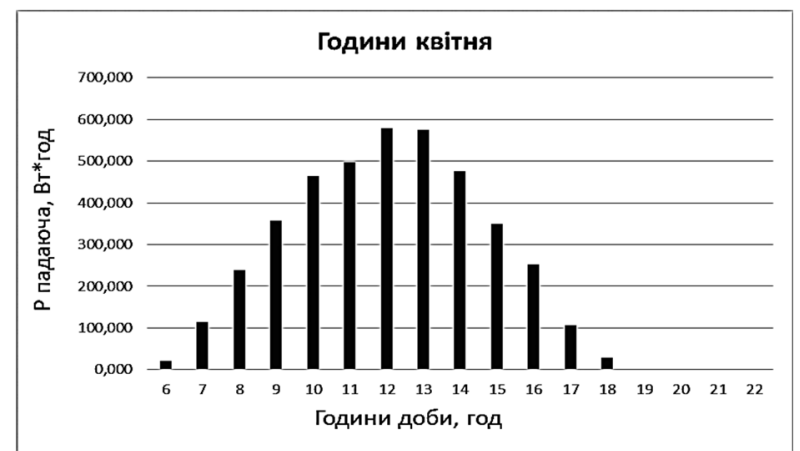

б

Рис. 2. Середньомісячні добові погодинні розподіли енергї сумарної СР, щуо надходить на $1 \mathrm{M}^{2}$ оптимально розміщеної ФЕП у січні (а) та квітні (б) у м. Львові, розраховані за даними 2013 р.

Погодинні кількості ЕЕ на виході з ФЕП можна розрахувати, використавши такий вираз:

$$
E_{\text {ФЕП }}=\eta_{\Phi Е \Pi} A_{\Phi Е \Pi} W
$$

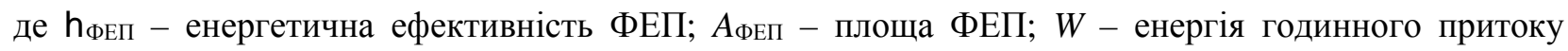
сонячної радіації на одиницю площі ФЕП. 


\section{I. З. Щур, Т. В. Галайко, Т. Я. Дзьоба}

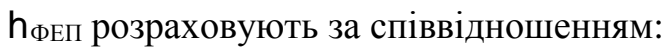

$$
\eta_{\text {ФЕП }}=\eta_{\mathrm{k}} \eta_{\mathrm{t}}\left[1-\mu\left(\theta_{\mathrm{p}}-25\right)\right]
$$

де $\eta_{\mathrm{k}}-$ ККД ФЕП; $\eta_{\mathrm{t}}-$ ККД системи відстеження точки максимуму відбору потужності ФЕП; прийнято, що він дорівнює 1, вважаючи, що система керування працює ефективно; $\mu$ - температурний коефіцієнт потужності ФЕП, який приймається сталим і становить для кремнієвих ФЕП 0,004-0,006 ${ }^{\circ} \mathrm{C}^{-1}$.

Для побудови домашньої сонячної електростанції застосовано ФЕУ, створеному 3 полікристалічних ФЕП типу Ulica Solar 345W Poly Half-Cell 9BВ, із добрим співвідношенням цінаякість, які пропонують на ринку України [18]. Сонячна панель складається 3144 половинчастих фотоелементів (технологія Half Cell). У кожній комірці налічується дев'ять струмопровідних шин (технологія МBB). 3 лицьового боку кремнієві пластини захищені прозорим загартованим склом. Ззаду панелі містяться пластиковий лист і розподільна коробка. Вся багатошарова конструкція поміщена в раму з анодованого алюмінію. Слугує така ФЕП не менше ніж 25 років.

Для встановлення індивідуальної СЕС максимальної дозволеної потужності 30 кВт необхідно застосувати 87 ФЕП $(m=30 / 0,345=86,96)$. Якщо врахувати, що необхідна для безтрансформаторного мережевого інвертора вхідна постійна напруга повинна становити близько 550 В, то в одну гілку треба послідовно увімкнути $N_{\text {пос }}=15$ ФЕП (37,6 В $15=564$ В). Тоді для отримання необхідної потужності сонячної станції треба взяти $N_{\text {пар }}=6$ гілок. Отримана пікова потужність станції становитиме

$$
P_{\text {CEC }}=N_{\text {пос }} N_{\text {пар }} P_{1 . \text { н }}=15 \cdot 6 \cdot 0,345=31,05 \text { кВТ }
$$

за загальної кількості ФЕП $m=N_{\text {пос }} \cdot N_{\text {пар }}=15 \cdot 6=90$, де $P_{1 . н}-$ номінальна потужність однієї ФЕП.

Враховуючи, що корисна площа однієї ФЕП становить 1,984 м², загальна активна світлосприймальна площа ФЕУ становитиме $A_{\text {ФЕУ }}=1,984 \cdot 90=178,56$ м².

Виконавши розрахунки за виразами (11) та (12) для кожної години середнього дня місяця, для нашої СЕС отримали погодинні кількості генерованої ЕЕ, необхідні для подальших розрахунків. Після їх додавання протягом світлового дня одержано сумарні кількості генерованої за середній день місяця ЕЕ, які наведено на рис. 3.

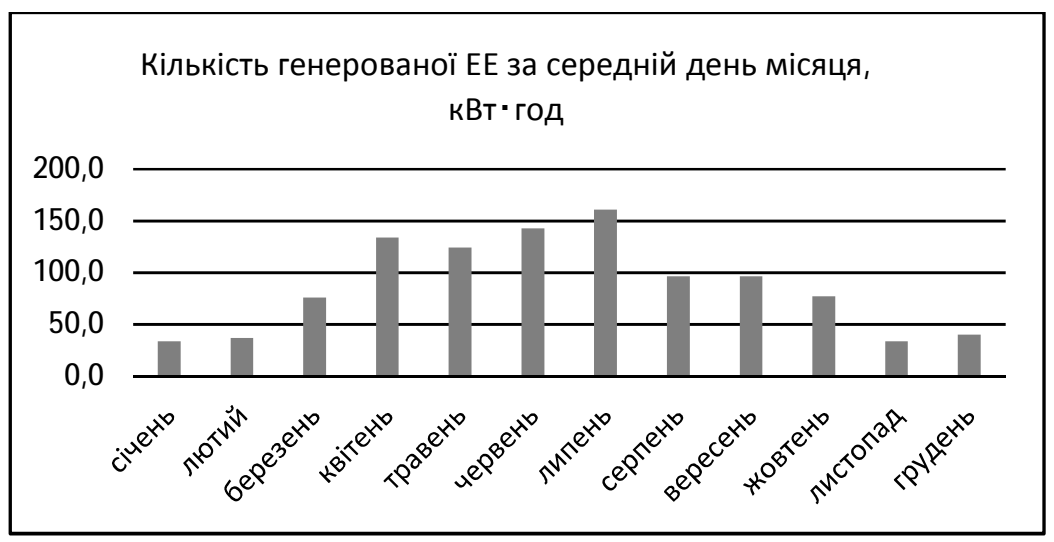

Рис. 3. Щоденні кількості ЕЕ, які генерує досліджувана СЕС у різні місяиі року

\section{Розроблення методики визначення економічної ефективності роботи СЕС в інди- відуальному домогосподарстві}

Основним компонентом СЕС є ФЕП. У зв'язку з розвитком напівпровідникових техно-

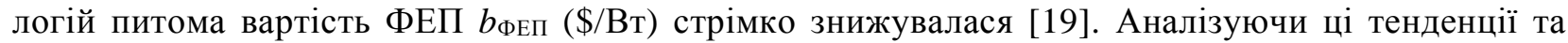
екстраполюючи їх, на рис. 4 ми побудували орієнтовну часову залежність питомої вартості ФЕП на 2015-2025 рр., яку приймемо для подальших розрахунків. 
Економічна ефективність сонячної електростаниії в індивідуальному домогосподарстві...

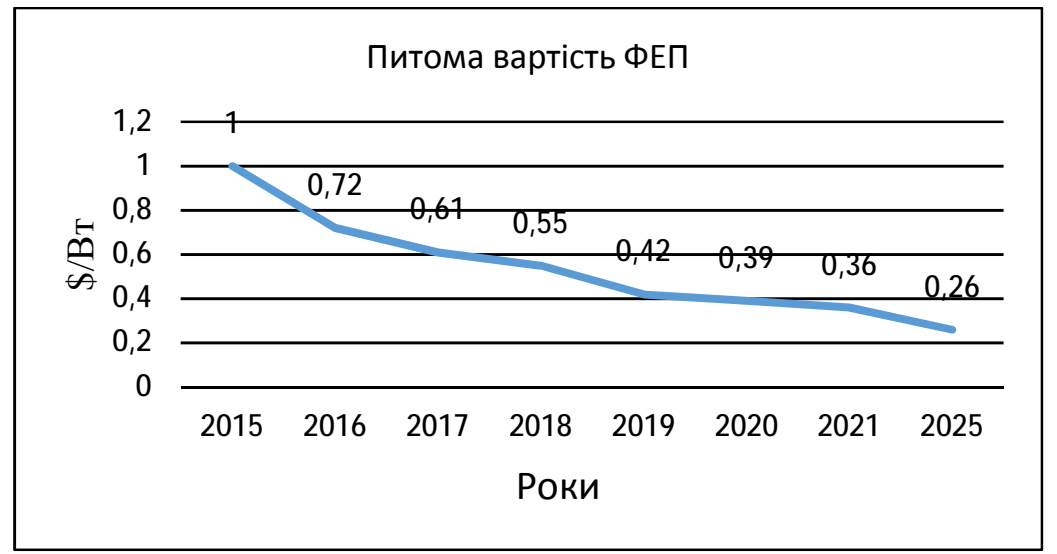

Рис. 4. Питома вартість ФЕП, прийнята у розрахунках

Показану на рис. 4 криву, для подальших електронних розрахунків, доцільно апроксимувати. Застосувавши програму CURVEXPERT, 3 коефіцієнтом кореляції 0,9894 отримали таку квадратичну залежність:

$$
b_{\text {ФЕП }}=70642,6-69,912 t_{\mathrm{p}}+0,0172975 t_{\mathrm{p}}^{2} \quad[\$ / \mathrm{BT}],
$$

де $t_{\mathrm{p}}$ - час, календарних років.

Крім ФЕП, до складу СЕС входять й інші компоненти: система кріплення, мережевий інвертор, двонаправлений лічильник ЕЕ, монтажні матеріали. Крім цього, до сумарної вартості СЕС необхідно додати й витрати на транспортування обладнання та монтажні роботи. Сумарні витрати на побудову СЕС можна орієнтовно прийняти в 1,5 разу вищими, ніж вартість ФЕП, і в подальших розрахунках визначати за виразом

$$
B_{\text {СЕС }}=1,5 N_{\text {пос }} N_{\text {пар }} P_{1 . \text { н }} b_{\text {ФЕП }} \cdot
$$

Для кошторисного аналізу СЕС використано методику, згідно з якою вартість будь-якої системи електроживлення, крім ціни на обладнання, залежить від інших чинників, таких як інфляція чи ставка дисконтування, які, своєю чергою, залежать від поточної економічної ситуації в країні. Тому під час розрахунку вартості обладнання СЕС ці чинники були враховані, оскільки вони дають змогу оцінити реальну вартість установки. У дослідженні враховано також витрати на обслуговування елементів системи протягом усього терміну ії експлуатації ( $n=20$ років). Ці витрати прийнято в розмірі $1 \%$ від ціни устаткування.

Кошторисний аналіз СЕС здійснено на основі методики, викладеної в [3, 20].

Насамперед необхідно розрахувати загальну річну вартість СЕC - TAC (Total Annualized Cost) за таким співвідношенням:

$$
\mathrm{TAC}=\frac{\mathrm{TLCC}}{\mathrm{CPWF}},
$$

де TLCC (Total Life Cycle Cost) - загальна вартість системи протягом періоду експлуатації; CPWF (Cumulative Present Worth Factor) - сукупний фактор теперішньої вартості.

CPWF залежить від рівня інфляції та ставки дисконтування і з використанням цього фактора можна оцінити поточну вартість СЕС, на основі грошових потоків, які прогнозують на майбутнє, за умови їх зміни протягом періодів прогнозування. CPWF розраховано за таким виразом:

$$
\mathrm{CPWF}=\frac{1-X^{n}}{1-X} .
$$

Змінну $X$ розраховують за таким співвідношенням:

$$
X=\frac{1+i}{1+d},
$$

де $i$ - рівень інфляції; $d$ - ставка дисконтування (коефіцієнт, що застосовують для визначення поточної вартості грошових потоків, які планують у майбутньому). 
Для СЕС, яка працює паралельно з мережею живлення, надлишкова ЕЕ віддається в мережу. Річний прибуток від роботи мережевої CEC - TIOES (Total Income of Energy Sold) можна розрахувати за виразом

$$
\mathrm{TIOES}=\Pi_{\text {над }}-B_{\text {мер }}-\mathrm{TAC},
$$

де $\Pi_{\text {над }}-$ річний прибуток від продажу надлишкової ЕЕ в мережу за "зеленим" тарифом; $B_{\text {мер }}$ - річна вартість за спожиту з мережі EЕ.

Для отримання $\Pi_{\text {над }}$ та $B_{\text {мер}}$, відповідно до розробленого алгоритму, обчислено баланс ЕЕ кожної $i$-ї години середнього дня $j$-го місяця $з$ урахуванням як усередненого для певних місяця $\mathrm{i}$

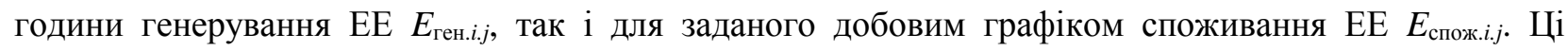
баланси можна виразити так:

- надлишкова ЕЕ, що віддається у мережу

$$
E_{\text {над. } ., j}=\left\{\begin{array}{ll}
E_{\text {ген. } ., j}-E_{\text {спож. } ., j}, & \text { якщо } E_{\text {ген. } ., j} \geq E_{\text {спож. } ., j} \\
0, & \text { якщо } E_{\text {ген. } ., j}<E_{\text {спож. } ., j}
\end{array} ;\right.
$$

- додаткова ЕЕ, що споживається з мережі

$$
E_{\text {мер. } ., j}=\left\{\begin{array}{ll}
0, & \text { якщо } E_{\text {ген. } ., j} \geq E_{\text {спож. } ., j} \\
E_{\text {спож. } i, j}-E_{\text {ген. } ., j, j}, & \text { якщо } E_{\text {ген } ., j, j}<E_{\text {спож. } i, j}
\end{array} .\right.
$$

Отриманий добовий баланс надлишкової ЕЕ, що віддається у мережу, та додаткової спожитої 3 мережі ЕЕ прямо поширений на місяць:

$$
E_{\text {над. } . j}=m_{j} \sum_{i=1}^{24} E_{\text {над. } . i, j} ; \quad E_{\text {мер. } . j}=m_{j} \sum_{i=1}^{24} E_{\text {мер. } ., j},
$$

де $m_{j}$ - кількість днів у $j$-му місяці.

Місячні кількості ЕЕ далі підсумовують у річні:

$$
E_{\text {над }}=\sum_{j=1}^{12} E_{\text {над. } j} ; \quad E_{\text {мер }}=\sum_{j=1}^{12} E_{\text {мер } . j} .
$$

Припускаючи, що “зелений” тариф $T_{3}$ упродовж року не змінюється, $\Pi_{\text {над }}$ можна розрахувати за виразом $\Pi_{\text {над }}=E_{\text {над }} T_{3}$.

Оскільки уже відмінено диференційований тариф на ЕE, що споживають побутові споживачі, то річна вартість спожитої з мережі ЕЕ становить $B_{\text {мер }}=E_{\text {мер }} T_{\mathrm{EE}}$, де $T_{\mathrm{EE}}-$ тариф на ЕЕ.

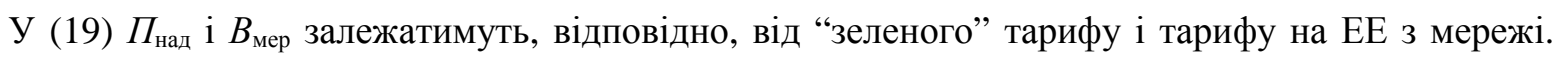
Розрахунок значення річного критерію TIOES теж залежатиме й від встановленої потужності i, відповідно, вартості СЕС. Цей критерій покаже, яку СЕС варто встановлювати у домогосподарстві за конкретних тарифних умов.

Сумарний прибуток від використання СЕС можна визначити як суму значень критерію TIOES за увесь термін експлуатації CEC, який прийнято 25 років. Термін окупності СЕС визначатиметься часом, за який сума різниць $\left(\Pi_{\text {над }}-B_{\text {мер }}\right)$ перевищить початкову сукупну вартість CEC.

Оскільки обладнання для СЕС переважно імпортне, і його закупівельна вартість виражена у доларах США, а до “твердої” валюти прив” язаний “зелений” також тариф в Україні, то і розрахунки в дослідженні виконано в доларах США.

Для подальших розрахунків необхідні дані про тариф на ЕЕ для населення, його динаміку в минулому та прогноз на майбутне. Про динаміку тарифу на ЕЕ для побутових споживачів можна робити висновки за даними регулятора - Національної комісії, що здійснює державне регулювання у сферах енергетики та комунальних послуг (НКРЕКП). Як видно з [21], у 2015-2017 рр. тариф стрімко зростав, приблизно на $25 \%$ щопівроку. Нині тарифи 2017 р. не змінилися, лише ліквідовано базові знижені тарифи для перших 100 і 150 кВт.год для населення, відповідно, 
сільської та міської місцевостей. Проте постійно триває дискусія між політиками й спеціалістами у сфері електроенергетики про необхідність підвищення тарифів на ЕЕ, оскільки сучасні тарифи вже давно є дотаційними. Як аргумент наводять тарифи в різних країнах Європи, які в кілька разів вищі, ніж в Україні. Це дає підстави для висновку, що тариф на ЕЕ для населення в Україні зростатиме, особливо у разі зростання економіки.

Для подальших розрахунків орієнтовно прийнято динаміку тарифу на ЕЕ для побутових споживачів у вигляді, показаному на рис. 5.

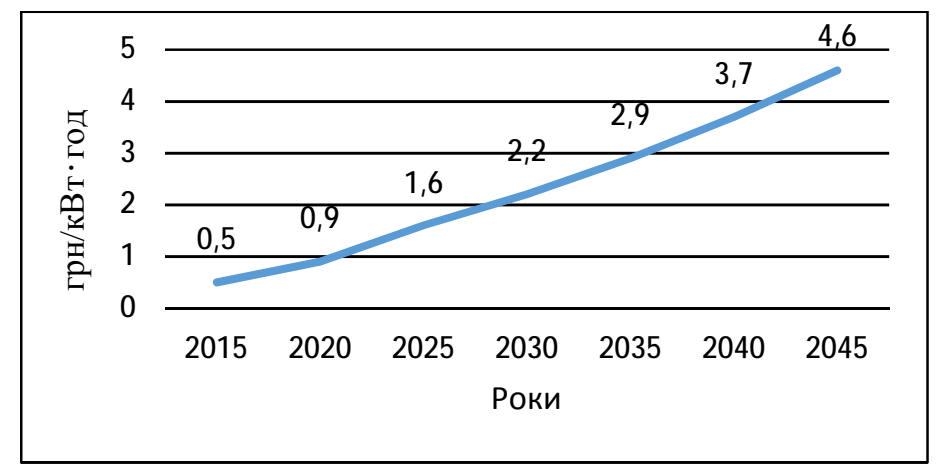

Рис. 5. Прогноз тарифу на ЕЕ для побутових споживачів в Украӥні на період до 2045 p.

Подану на рис. 5 прогнозну криву для подальших електронних розрахунків апроксимовано 3 коефіцієнтом кореляції 0,9996 квадратичною залежністю:

$$
T_{\text {EЕ }}=6003,26-6,0495 t_{\mathrm{p}}+0,0015238 t_{\mathrm{p}}^{2} \text { [грн/кВт } \square \text { год], }
$$

де $t_{\mathrm{p}}$ - час, календарних років.

Тариф (24) закладено в програму, що реалізується в Excel, для розрахунку економічних показників.

Порівняння економічної ефективності роботи СЕС в індивідуальному домогосподарстві за різних сценаріїв динаміки “зеленого" тарифу

Зважаючи на складність ситуації із "зеленим" тарифом на ВДЕ в Україні, надалі можливі різні стратегії його зміни. У цьому дослідженні розглянуто два сценарії зміни “зеленого" тарифу на $\mathrm{EE}$, що генерується із сонячної енергії у домашніх CEC, які, на наш погляд, $\epsilon$ цілком вірогідними.

Сценарій 1 (песимістичний). До 2030 р., що передбачено чинним Законом України “Про альтернативні джерела енергіі”, “зелений” тариф переважно збереже тенденцію до незначного зниження, як це вже відбувалося у 2015-2020 рр., проте залишатиметься на достатньо високому рівні (рис. 6).

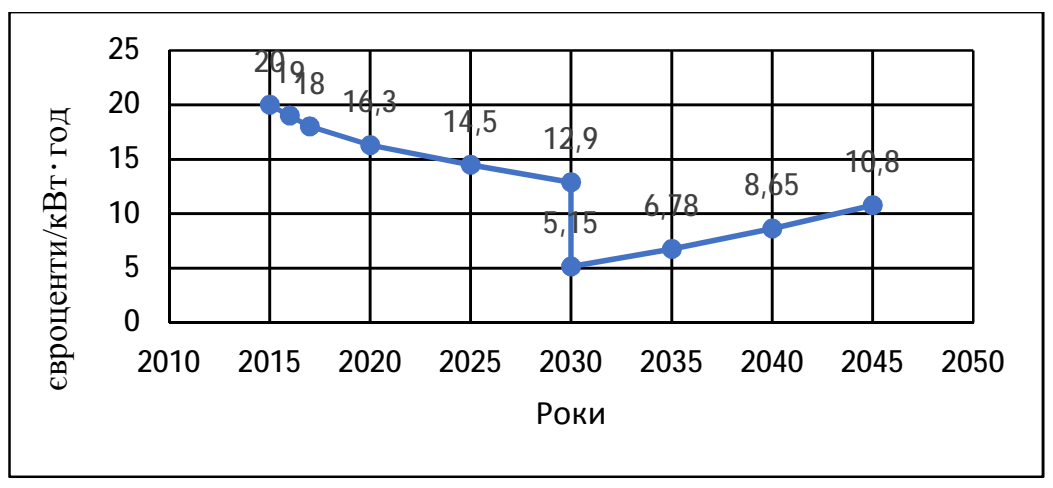

Рис. 6. Сценарій 1 зміни “зеленого” тарифу на ЕE, щзо генерується у домашніх СЕС 
Після закінчення дії вказаного закону у 2030 р., зважаючи на погане економічне становище в Україні та, відповідно, поганий стан з платежами за ЕE, “зелений” тариф буде різко знижений. Це відповідає сценарієві, яким пішли передові країни Європи. Наприклад, в Польщі вже нині “зелений” тариф на ВДЕ становить 0,8 від тарифу на EЕ, що споживається з мережі живлення. Це обгрунтовують тим, що електромережа розглядається як акумулятор надлишкової генерованої ЕЕ, яку споживач не може сам використати у цей момент, а за акумулювання цієї ЕЕ необхідно заплатити 20 \% від вартості ЕЕ. Власники електромереж заробляють за послугу зберігання ЕЕ і мають додаткові кошти на “боротьбу" із нестабільністю генерування ЕЕ від ПДЕ. Для стимулювання розвитку альтернативної енергетики у цих країнах застосовують інші механізми, ніж “зелений” тариф, наприклад, державні дотації на придбання обладнання. Відповідно до цієї логіки, після 2030 р. “зелений” тариф становитиме 0,8 від тарифу на ЕЕ. На рис. 6 цей тариф розраховано на основі прогнозної кривої тарифу на ЕЕ, показаної на рис. 5. 3 метою подальших розрахунків монотонні частини кривої, наведеної на рис. 6, апроксимовано за допомогою програми CURVEXPERT такими квадратичними виразами:

- для періоду 2015-2030 pp.

$$
T_{3.1 .1}=87305-85,87 t_{\mathrm{p}}+0,0211177 t_{\mathrm{p}}^{2} \quad \text { [євроценти /кВт · год]; }
$$

- для 2030-2045 pp.

$$
T_{3.1 .2}=20828,1-20,8136 t_{\mathrm{p}}+0,00520 t_{\mathrm{p}}^{2} \quad \text { [євроценти /кВТ } \cdot \text { год]. }
$$

Сценарій 2 (оптимістичний). Після 2030 р. загалом збережеться тенденція до незначного зниження "зеленого" тарифу, як це вже відбувалося у 2015-2020 pp. Він залишатиметься на достатньо високому рівні аж до 2045 р., як показано на рис. 7.

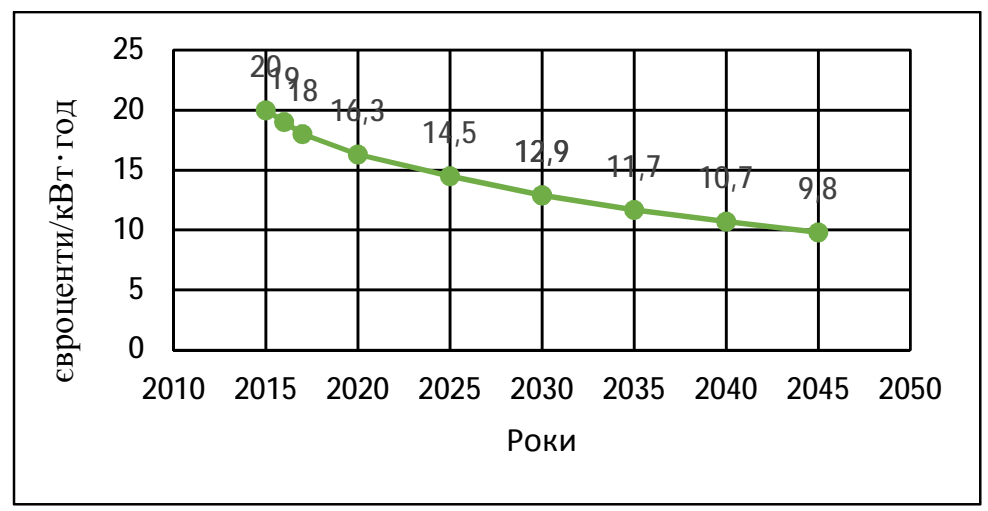

Pис. 7. Сценарій 2 зміни “зеленого” тарифу на EE, що генерується у домашніх СЕС

Наведену на рис. 7 криву апроксимовано таким квадратичним виразом:

$$
T_{3.2}=36433,2-35,568 t_{\mathrm{p}}+0,0086832 t_{\mathrm{p}}^{2} \quad \text { [євроценти /кВт · год]. }
$$

Для подальших розрахунків необхідно вибрати параметри конкретного типового домогосподарства, у якому буде встановлюватися СЕС. Вибрано котедж, розташований на околиці Львова, сучасний варіант, коли в індивідуальному будинку повністю відсутне газопостачання $\mathrm{i}$ тому споживач для обігрівання будинку використовує одноконтурний електричний котел. Оскільки у споживача постійно є необхідність у гарячому водопостачанні, то одноконтурний котел використовується разом з електричним бойлером.

Отож, розглянемо одноконтурний електричний котел з номінальною потужністю 10 кВт, який працюватиме тільки в опалювальний сезон, тобто з 1 жовтня до 30 квітня включно. Помісячну 
Економічна ефективність сонячної електростаниії в індивідуальному домогосподарстві...

інтенсивність його роботи задано такими значеннями коефіцієнта використання номінальної потужності котла: жовтень - 0,2; листопад - 0,3; грудень - 0,4; січень - 0,5; лютий $-0,45$; березень - 0,3; квітень - 0,2. Гарячу воду в будинку використовують зранку з $7^{00}$ до $9^{00}$ та ввечері з $19^{00}$ до $21^{00}$. Для розрахунку кількості $\mathrm{EE} W_{\text {}}$, що витрачається на підігрівання води, використано таке співвідношення:

$$
W_{\mathrm{B}}=\frac{c_{\mathrm{B}} \rho_{\mathrm{B}} V_{\text {гв. }}\left(\theta_{\mathrm{B}^{*}}-\theta_{\text {ви }}\right) n_{\text {ж }}}{3,6 \cdot 10^{6}},
$$

де $c_{\text {в }}$ - питома теплоємність води; $\rho_{\text {в }}$ густина води; $V_{\text {г.в. }}-$ об'єм гарячої води, необхідний для однієї особи на день; $\theta_{\mathrm{B}^{*}}$ - бажана температура, до якої необхідно нагріти воду; $\theta_{\text {вп }}$ температура води у водопроводі; $n_{\text {ж }}$ кількість жителів в індивідуальному будинку.

Також до ГЕН додалось додаткове електроспоживання через використання кондиціонера влітку. Вибрали кондиціонер з номінальною електричною потужністю 3 кВт, який працюватиме лише влітку. Місячні коефіцієнти використання потужності кондиціонера для літнього періоду взято такими: червень - 0,7 ; липень $-1,0$; серпень $-0,8$.

Крім того, вважалось, що господарі котеджу використовують велику кількість побутової техніки із електроживленням. Орієнтовний графік електричного навантаження (ГЕН) такого споживача оцінено кривими погодинного навантаження з посезонним коригуванням, як показано на рис. 8 [16]. Такий ГЕН потребує доволі велику кількість ЕЕ: взимку 1300 кВт·год/місяць, навесні 662 кВт·год/місяць, влітку 735 кВт·год/місяць і восени 1148 кВт·год/місяць.

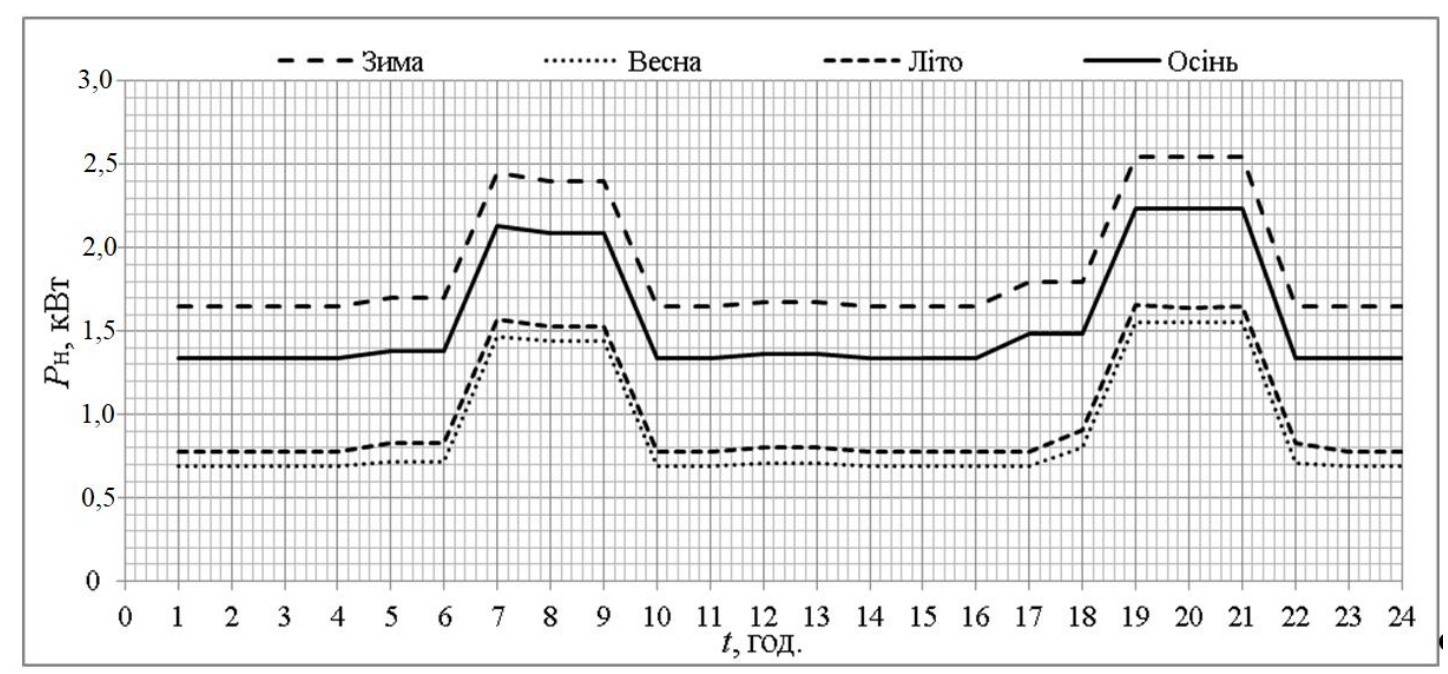

Рис. 8. Добовий ГЕН індивідуального котеджу з посезонним коригуванням

Для досліджуваного споживача потрібну потужність ФЕУ можна оцінити за значеннями критерію TIOES. Щоб визначити його відповідно до (16), спочатку треба обчислити значення ТАC. Загальну вартість CEC протягом періоду її експлуатації TLCC необхідно обчислювати за виразом

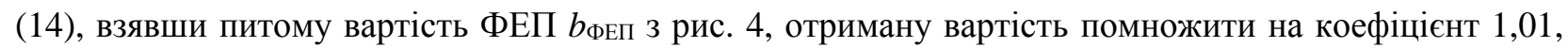
який враховує вартість обслуговування СЕС. Прийнявши річний рівень інфляції $10 \%$, а ставку дисконтування $16 \%$, за виразом (18) визначили $X=0,9482$. Далі за виразом (17), взявши термін експлуатації CEC $n=20$ років, отримали $\mathrm{CPWF}=6,75$.

Подальші обчислення виконано із застосуванням електронних таблиць для різної сумарної

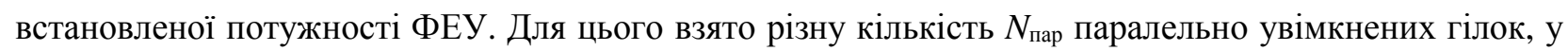
кожній з яких послідовно увімкнено $N_{\text {пос }}=15 \cdot$ ФЕП. Параметри досліджуваних варіантів ФЕУ подано в таблиці. 


\section{I. З. Щур, Т. В. Галайко, Т. Я. Дзьоба}

\section{Параметри досліджуваних варіантів ФЕУ}

\begin{tabular}{|c|c|c|c|c|}
\hline № варіанта & $N_{\text {пар, }}$ шт. & $m$, шт & $P_{\text {ФЕу, КВТ }}$ & $A_{\text {ФЕУ, }}{ }^{2}$ \\
\hline 1 & 1 & 15 & 5,175 & 29,76 \\
\hline 2 & 2 & 30 & 10,35 & 59,52 \\
\hline 3 & 3 & 45 & 15,525 & 89,28 \\
\hline 4 & 4 & 60 & 20,7 & 119,04 \\
\hline 5 & 5 & 75 & 25,875 & 148,8 \\
\hline 6 & 6 & 90 & 31,05 & 178,56 \\
\hline
\end{tabular}

Для кожного з шести вказаних у табл. 1 варіантів за викладеною методикою для кожної години кожного середнього дня місяця визначено кількості ЕЕ, яка генерується СЕС і споживається, а також віддається чи береться від мережі. За місячними балансами, відповідно до

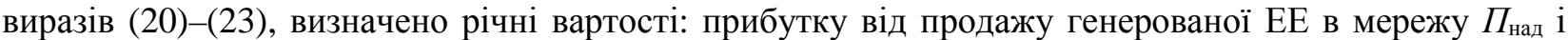

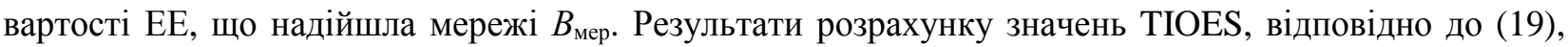
для трьох років встановлення СЕС наведено на рис. 9. Аналіз цих результатів показує, що для СЕС, встановленої у 2016 р., з метою отримання прибутку потрібно більше ніж 3,5 паралельної гілки ФЕП, тобто встановлена потужність ФЕУ повинна перевищувати $3,5 \cdot 15 \cdot 0,345=18,1$ кВт. У 2018 р. для цього вже було достатньо двох гілок, тобто необхідно встановити 10,4 кВт, а для 2020 р. тільки 1,75 гілки, тобто 9,0 кВт ФЕУ. Це пояснюється стрімким зниженням вартості ФЕП, темп якого явно перевищує темпи зменшення “зеленого” тарифу і зростання тарифу на ЕЕ. Звичайно, що більша потужність ФЕУ, то вигіднішою буде СЕС. Тому надалі розглянемо СЕС максимально дозволеної для побутових споживачів потужності з шістьма паралельними гілками ФЕП і їх загальною кількістю 90 шт.

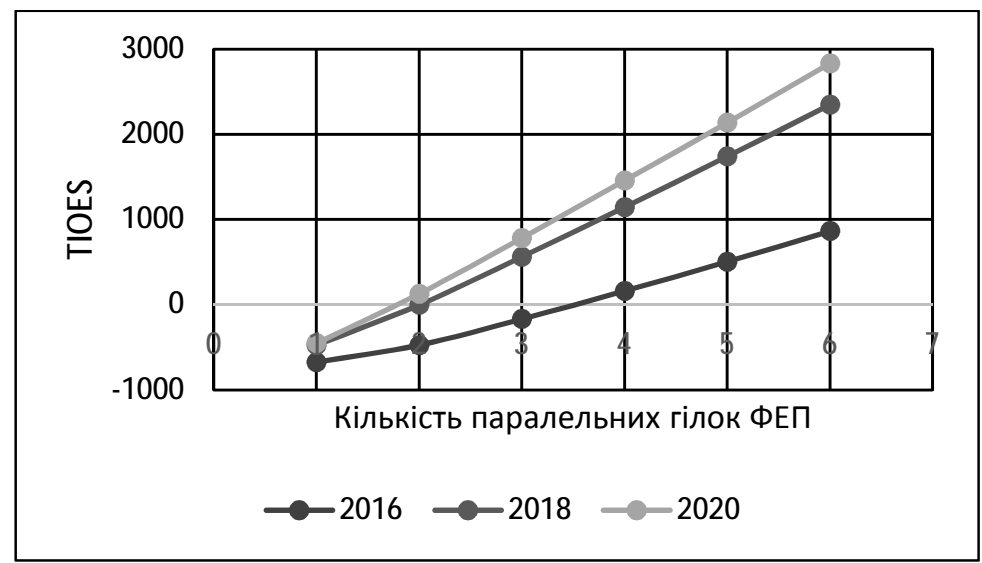

Рис. 9. Залежності критерію TIOES від кількості паралельних гілок ФЕП для різних років встановлення СЕС

Використовуючи розроблену обчислювальну електронну таблицю, а також можливість швидкого отримання погодинних, помісячних і річних кількостей генерованої від ФЕУ, використаної споживачем, відданої в мережу надлишкової чи отриманої з мережі ЕЕ, якої недостатньо, виконано розрахунки отримання прибутку кожного року з урахуванням зміни “зеленого" тарифу за прийнятими сценаріями (25)-(27) та зміни тарифу на EE (24).

Річний прибуток від експлуатації СЕС (без урахування ії початкової вартості) обчислено за виразом

$$
\Delta \Pi=\Pi_{\text {над }}-B_{\text {мер }}-B_{\text {обсл }},
$$


Економічна ефективність сонячної електростаниії в індивідуальному домогосподарстві...

у якому річна вартість обслуговування дорівнює

$$
B_{\text {обсл }}=\frac{0,01 B_{\mathrm{CEC}}}{T_{\text {експ }}},
$$

де $B_{\mathrm{CEC}}$ - сумарна вартість СЕС, обчислена за виразом (3.2); $T_{\text {експ }}-$ термін експлуатації СЕС.

Термін окупності СЕС визначено графічно, коли сума прибутків, обчислених за (29), перевищить TLCC.

Розрахунки виконано для СЕС потужністю 30 кВт, встановлених у 2015 р. та 2021 р., які працюватимуть протягом терміну служби 25 років за сценарію 1 (песимістичного) та і сценарію 2 (оптимістичного) зміни “зеленого” тарифу.

Результати розрахунків для вказаних варіантів наведено на рис. 10, $a$ і $б$. Як видно з них, час встановлення СЕС впливає на отриманий прибуток від експлуатації СЕС: хоча швидше встановлена CEC довше працює в умовах високого “зеленого” тарифу та нижчого тарифу на ЕЕ, початкова висока вартість СЕС (46350 \$ для СЕС, встановленої в 2015 р., проти 15722 \$ для СЕС, встановленої в 2021 р.) зумовлює менший прибуток за обох сценаріїв зміни “зеленого” тарифу. Ця сама обставина забезпечує значно коротший термін окупності для СЕС, встановленої в 2021 р., лише 2,3 року проти семи років для СЕС, встановленої в 2015 р. Якщо порівняти отриманий прибуток за час експлуатації СЕС, то для оптимістичного сценарію він буде більшим порівняно 3 песимістичним сценарієм: в 1,43 разу для СЕС, встановленої в 2015 р., та в 1,35 разу для СЕС, встановленої в 2021 p.

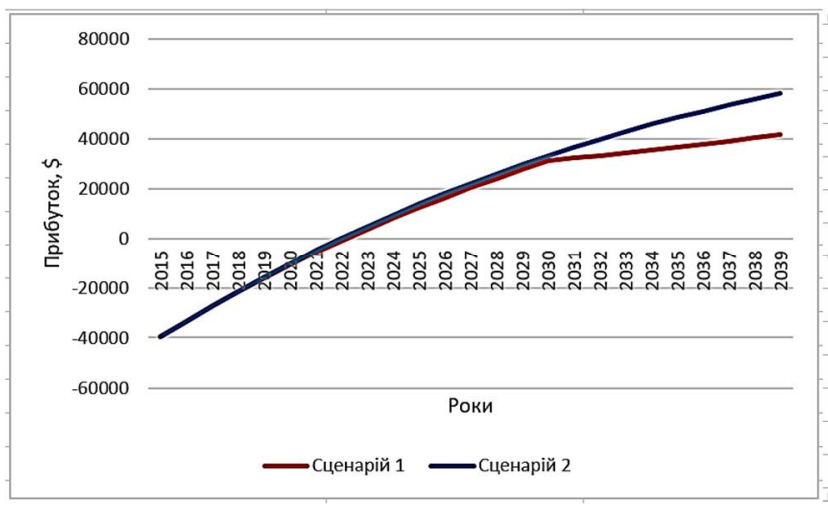

$a$

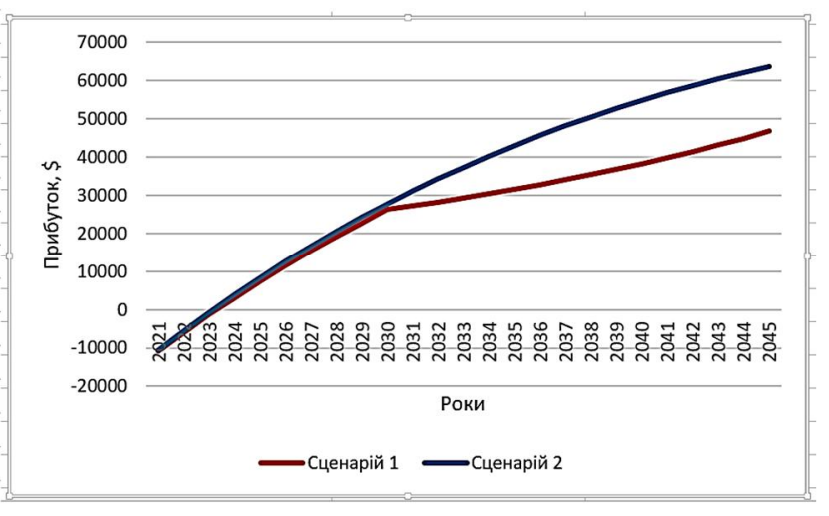

$\sigma$

Рис. 10. Залежності прибутку від експлуатайї СЕС потужністю 30 кВт, встановлених y 2015 р. (а) та в 2021 р. (б), для двох сценаріїв зміни “зеленого” тарифу

\section{Висновки}

У результаті проведеного дослідження можна зробити такі висновки.

1. Запровадження високого “зеленого” тарифу в Україні стимулювало бурхливий розвиток сонячної електроенергетики останніми роками. Проте тепер це вже стало проблемою через негативний вплив великих СЕС на стійкість електромереж та занадто високий “зелений” тариф, який розподіляється на усіх електроспоживачів.

2. Для отримання максимального прибутку від встановлення СЕС у приватному домогосподарстві доцільно встановлювати максимально допустиму потужність СЕС, особливо якщо власне електроспоживання високе. Запропонована методика розрахунку та розроблене програмне забезпечення дають змогу оперативно встановити мінімальну потужність (корисну площу) ФЕУ, у разі перевищення якої можна отримувати прибуток від експлуатації СЕС у домогосподарстві 3 конкретним графіком добового електроспоживання. 


\section{3. Щур, Т. В. Галайко, Т. Я. Дзьоба}

3. Проведені дослідження показали, що на термін окупності СЕС найбільше впливає рік їі встановлення. У СЕС, встановлених пізніше, значно коротший термін окупності, що пов'язано зі стрімким зниженням вартості ФЕП.

4. Розглянуті варіанти оптимістичного і песимістичного сценаріїв динаміки «зеленого» тарифу показали, що за оптимістичного сценарію можна отримати на 30-40 \% більший прибуток від експлуатації СЕС порівняно з песимістичним сценарієм, незалежно від року встановлення СЕС.

5. У подальших дослідженнях доцільно в розроблену методику ввести модель деградації ФЕП в процесі експлуатації, а також розглянути вплив застосування зонного тарифу на ЕЕ на термін окупності СЕС.

\section{Список літератури}

1. Закон про Зелений тариф на електроенергію. URL: https://utem.org.ua/ua/cats/zakon_o_ zelenom_tarife

2. Liqun L. Feasibility analyses of hybrid wind-PV-battery power system in Dongwangsha, Shanghai / L. Liqun, L Chunxia // Przeglad Elektrotechniczny. 2013. No. 1a. P. 239-242. ISSN 0033-2097

3. Kaabeche A. Techno-economic valuation and optimization of integrated photovoltaic/wind energy conversion system / A. Kaabeche, M. Belhamel, R. Ibtiouen // Solar Energy. 2011. Vol. 85. P. 2407-2420. DOI:10.1016/j.solener.2011.06.032

4. Setiawan A. A. Design, economic analysis and environmental considerations of mini-grid hybrid power system with reverse osmosis desalination plant for remote areas / A. A. Setiawan, Y. Zhao, C. V. Nayar // Renewable Energy. 2009. Vol. 34. P. 374-383. DOI:10.1016/j.renene.2008.05.014

5. Kumar N.M. Impact of Performance Degradation and Capital Subsidy on the Revenue of Rooftop PV System / N.M Kumar, N. Prabaharan, A. Rini Ann Jerin, A. Jayakumar // Int. J. of Renewable Energy Research. 2019. Vol. 9, No. 1. P. 120-136. ISSN: 1309-0127

6. Bondarchuk A. S. Research of the efficiency of hybrid solar collectors as sources of electrical and thermal energy for the housing microregion of the city / A. S. Bondarchuk, O. P. Hoholyuk, Iu. A. Shullie // Slovak Int. Scientific J. 2018. Vol. 1, No. 17. P. 14-21.

7. Хаикевич Ю. В. Методика розрахунку техніко-економічних показників роботи системи електропостачання з фотоелектричними елементами / Ю. В. Хачкевич, І. М. Лученко, М. В. Александров // Строительство, материаловедение, машиностроение. 2016. Вып. 92. С. 163-172.

8. Як зміниться ринок енергетики України в 2019 році - огляд законодавства. URL: https://greencubator. info/energy-new-rules-2019

9. Що таке зелений тариф і чому ие стосується всіx. URL: https://lb.ua/economics/2020/07/22/ 462344_shcho_take_zeleniy_tarif_i_chomu_tse.html

10. Встигнути до 2030 року: чому в Украӥні спостерігається бум інвестииій в “зелену" енергетику $i$ що зміниться на ринку в 2020 роиi? URL:https://getmarket.com.ua/ua/news/vstignuti-do-2030-roku-choти-vukrayini-sposterigayet-sya-bum-investicij-v-zelenu-energetiku-i-sho-zminit-sya-na-rinku-v-2020-roci

11. ВДЕ після підписання Меморандуму про взаєморозуміння. Що далі? URL: https://home.kpmg/ua/uk/ home/media/press-releases/2020/11/vde-pislya-pidpysannya-memorandumu-pro-vzayemorozuminnya.html

12. Radosavljevic J. Defining of the intensity of solar radiation on horizontal and oblique surfaces on earth / J. Radosavljevic, A. Dordevic // Working and Living Environmental Protection. 2001. Vol. 2, No. 1. P. 77-86.

13. El-Sebaii A. Global, direct and diffuse solar radiation on horizontal and tilted surfaces in Jeddah, Saudi Arabia / A. El-Sebaii, F. Al-Hazmi, A. Al-Ghamdi, S. Yaghmour // Applied Energy. 2010. Vol. 87. P. 568-576. DOI:10.1016/j.apenergy.2009.06.032

14. Шаповал С. Розрахунок сонячної енергії, що надходить на геліопанель [Текст] / С. Шаповал, М. Касинеиь, О. Дейнека // Вісник Наиіонального університету “Львівська політехніка”. 2012. № 742. С. 225-228.

15. Твайделл Д. Возобновляемые источники энергии [Текст] / Д. Твайделл, А. Уэйр; Пер. с англ. Москва: Энергоатомиздат, 1990. - 392 с. ISBN 5-283-02469-5

16. Климко В. І. Вітросонячні системи електроживлення малопотужних споживачів: дисертація ... канд. техн. наук. Львів, 2016. 214 с.

17. Климко В. Условия эффективной работы фотоэлектрических панелей. Опыт г. Львова / В. Климко, И. Щур // Энергетика и ТЭК. 2014. №11(140). С. 42-45. 
Економічна ефективність сонячної електростаниії в індивідуальному домогосподарстві...

18. Солнечная батарея Ulica Solar UL-345P-144, поликристалл, 9BB, Half-Cell. URL: https://ecotech.com.ua/ua/p1143760169-solnechnaya-batareya-ulica.html

19. Динамика изменения ценн на солнечные батареu. URL: https://newsland.com/community/4765/ content/dinamika-izmeneniia-tsen-na-solnechnye-batarei/5117605

20. Bilal B. Methodology to size an optimal stand-alone $\mathrm{pv/wind/diesel/battery} \mathrm{system} \mathrm{minimizing} \mathrm{the} \mathrm{levelized}$ cost of energy and the CO2 emissions / B. Bilal, V. Sambou, C. Kebe, P. Ndiaye, M. Ndongo // Energy Procedia. 2012. Vol. 14. P. 1636-1647. DOI:10.1016/j.egypro.2011.12.1145

21. Офіиійний сайт Національної комісій, щзо здійснює державне регулювання у сферах енергетики та комунальних послуг (НКДРЕКП). URL:https://www.nerc.gov.ua/?id=19527.

\section{References}

1. Zakon pro Zelenyy Taryf na elektroenerhiyu URL: https://utem.org.ua/ua/cats/zakon_o_zelenom_tarife.

2. Liqun L. Feasibility analyses of hybrid wind-PV-battery power system in Dongwangsha, Shanghai / L. Liqun, L Chunxia // Przeglad Elektrotechniczny. 2013. No. 1a. P. 239-242. URL: http://pe.org.pl/articles/ 2013/1a/58.pdf.

3. Kaabeche A. Techno-economic valuation and optimization of integrated photovoltaic/wind energy conversion system / A. Kaabeche, M. Belhamel, R. Ibtiouen // Solar Energy. 2011. Vol. 85. P. 2407-2420. DOI:10.1016/j.solener.2011.06.032.

4. Setiawan A.A. Design, economic analysis and environmental considerations of mini-grid hybrid power system with reverse osmosis desalination plant for remote areas / A. A. Setiawan, Y. Zhao, C. V. Nayar // Renewable Energy. 2009. Vol. 34. P. 374-383. DOI:10.1016/j.renene.2008.05.014.

5. Kumar N. M. Impact of Performance Degradation and Capital Subsidy on the Revenue of Rooftop PV System / N. M. Kumar, N. Prabaharan, A. Rini Ann Jerin, A. Jayakumar // Int. J. of Renewable Energy Research. 2019. Vol. 9, No. 1. P. 120-136. URL: https://www.ijrer.org/ijrer/index.php/ijrer/article/view/8808/pdf.

6. Bondarchuk A. S. Research of the efficiency of hybrid solar collectors as sources of electrical and thermal energy for the housing microregion of the city / A. S. Bondarchuk, O. P. Hoholyuk, Iu. A. Shullie // Slovak Int. Scientific J. 2018. Vol. 1, No. 17. P. 14-21.

7. Khatskevych Yu. V. Metodyka rozrakhunku tekhniko-ekonomichnykh pokaznykiv roboty systemy elektropostachannya z fotoelektrychnymy elementamy / Yu. V. Khatskevych, I. M. Lutsenko, M. V. Aleksandrov // Stroytel'stvo, materyalovedenye, mashynostroenye. 2016. Is. 92. P. 163-172.

8. Yak zminyt'sya rynok enerhetyky Ukrayiny $v 2019$ rotsi - ohlyad zakonodavstva URL: https://greencubator.info/energy-new-rules-2019.

9. Shcho take zelenyy taryf $i$ chomu tse stosuyet'sya vsikh URL: https://lb.ualeconomics/2020/07/22/ 462344_shcho_take_zeleniy_tarif_i_chomu_tse.html.

10. styhnuty do 2030 roku: chomu v Ukrayini sposterihayet'sya bum investytsiy $v$ "zelenu” enerhetyku $i$ shcho zminyt'sya na rynku v 2020 rotsi? URL:https://getmarket.com.ua/ua/news/vstignuti-do-2030-roku-chomu-vukrayini-sposterigayet-sya-bum-investicij-v-zelenu-energetiku-i-sho-zminit-sya-na-rinku-v-2020-roci

11. VDE pislya pidpysannya Memorandumu pro vzayemorozuminnya. Shcho dali? URL: https://home.kpmg/ ua/uk/home/media/press-releases/2020/11/vde-pislya-pidpysannya-memorandumu-pro-vzayemorozuminnya.html.

12. Radosavljevic J. Defining of the intensity of solar radiation on horizontal and oblique surfaces on earth / J. Radosavljevic, A. Dordevic // Working and Living Environmental Protection. 2001. Vol. 2, No. 1. P. 77-86. URL: http://facta.junis.ni.ac.rs/walep/walep2001/walep2001-09.pdf

13. El-Sebaii A. Global, direct and diffuse solar radiation on horizontal and tilted surfaces in Jeddah, Saudi Arabia / A. El-Sebaii, F. Al-Hazmi, A. Al-Ghamdi, S. Yaghmour // Applied Energy. 2010. Vol. 87. P. 568-576. DOI:10.1016/j.apenergy.2009.06.032.

14. Shapoval S. Rozrakhunok sonyachnoyi enerhiyi, shcho nadkhodyt' na heliopanel' [Tekst] / S. Shapoval, M. Kasynets', O. Deyneka // Visnyk natsional'noho universytetu “L'vivs'ka politekhnika”. 2012. № 742. P. 225-228. URL: http://ena.lp.edu.ua:8080/bitstream/ntb/18010/1/42-225-228.pdf.

15. Tvaydell D. Vozobnovlyayemyye istochniki energii [Tekst] /D. Tvaydell, A. Ueyr; Per. S angl. - Moskva: Energoatomizdat, 1990. - 392 p. ISBN 5-283-02469-5.

16. Klymko V. I. Vitrosonyachni systemy elektrozhyvlennya malopotuzhnykh spozhyvachiv. Dysertatsiya ... kand. tekhn. nauk. L'viv, 2016. 214 c. URL: https://pnu.ua/sites/default/files/2020/dissertation/ 1312/dissertatklymko.pdf.

17. Klimko V. Usloviya effektivnoy raboty fotoelektricheskikh paneley. Opyt g. L'vova / V. Klimko, I. Shchur // Energetika i TEK. 2014. № 11(140). P. 42-45. URL: http://www.energetika.by/arch/ year__m21= 2014 page_m21=1 news__m21=1366. 
18. Solnechnaya batareya Ulica Solar UL-345R-144, polikristall, 9BB, Half-Cell. URL: https://ecotech.com.ua/ua/p1143760169-solnechnaya-batareya-ulica.html.

19. Dinamika izmeneniya tsen na solnechnyye batarei URL: https://newsland.com/community/4765/ content/dinamika-izmeneniia-tsen-na-solnechnye-batarei/5117605.

20. Bilal B. Methodology to size an optimal stand-alone pv/wind/diesel/battery system minimizing the levelized cost of energy and the CO2 emissions / B. Bilal, V. Sambou, C. Kebe, P. Ndiaye, M. Ndongo // Energy Procedia. - 2012. - Vol. 14. - P. 1636-1647. DOI:10.1016/j.egypro.2011.12.1145.

21. Ofitsiynyy sayt Natsional'noyi komisiyi, shcho zdiysnyuye derzhavne rehulyuvannya u sferakh enerhetyky ta komunal'nykh posluh (NKDREKP) URL:https://www.nerc.gov.ua/?id=19527.

I. Z. Shchur

Lviv Polytechnik National University, Department of Electromechatronics and Computerized Electromechanical Systems, ihor.z.shchur@lpnu.ua

T. V. Halaiko

Lviv Polytechnik National University, Department of Electromechatronics and Computerized Electromechanical Systems, tetiana.v.halaiko@lpnu.ua

T. Y. Dzoba

Lviv Polytechnik National University, Department of Electromechatronics and Computerized Electromechanical Systems, dzoba@gmail.com

\section{ECONOMIC EFFICIENCY OF A SOLAR POWER PLANT IN AN INDIVIDUAL HOUSEHOLD UNDER DIFFERENT SCENARIOS OF GREEN TARIFF DYNAMICS}

(C) Shchur I. Z., Halaiko T. V., Dzoba T. Y., 2021

"Green" tariff - a special price at which electricity produced from renewable energy sources hydroelectric power plants, photovoltaic, wind turbines is purchased. Businesses and households that produce electricity at a "green" tariff sell it on the market much more expensively than traditional producers of thermal or nuclear energy. The paper analyzes the legislation and regulations on "green" tariff in Ukraine and the problems of their implementation. In particular, attention is paid to the use of solar power plants (SPP) in individual households. Based on the electronic information database of hourly regional meteorological data in Lviv generated in Microsoft Excel, the calculation of the average monthly hourly inflow of specific power of total solar radiation, which falls on stationary and optimally oriented photovoltaic panels, was conducted, and the power at their output was determined. Based on the results of the analysis of information from various sources, the dynamics of the costs of the main components for individual SPP was determined, as well as the analysis of the dynamics and forecast of the electricity tariff for the population in Ukraine were conducted. Based on the analysis of situation on the energy market of Ukraine, two possible scenarios of the dynamics of the "green" tariff for electricity generated in individual farms from solar energy are considered - optimistic and pessimistic. For each of these scenarios, based on the developed methodology, for SPP with a capacity of $30 \mathrm{~kW}$, installed in 2015 and 2021 in the studied typical version of household, their economic efficiency and payback period were determined. Studies have shown that the payback period of SPP is most affected by the year of its installation: SPP that are installed later have a much shorter payback period, which is associated with a sharp decline in the cost of photovoltaic panels. The considered variants of scenarios of dynamics of "green" tariff have shown that under the optimistic scenario it is possible to receive on 30-40 \% more profit from operation of SPP in comparison with the pessimistic scenario, irrespective of year of SPP installation.

Key words: "green" tariff; photovoltaic installation; solar power plant; renewable energy sources; hourly meteorological data. 